\title{
Screening of Microorganisms for Biodegradation of Simazine Pollution (Obsolete Pesticide Azotop 50 WP)
}

\author{
Magdalena Błaszak • Robert Pełech • \\ Paulina Graczyk
}

Received: 3 November 2010/Accepted: 21 January 2011 /Published online: 11 February 2011

(C) The Author(s) 2011. This article is published with open access at Springerlink.com

\begin{abstract}
The capability of environmental microorganisms to biodegrade simazine - an active substance of 2-chloro-s-triazine herbicides (pesticide waste since 2007) — was assessed. An enormous metabolic potential of microorganisms impels to explore the possibilities of using them as an alternative way for thermal and chemical methods of utilization. First, the biotope rich in microorganisms resistant to simazine was examined. Only the higher dose of simazine $(100 \mathrm{mg} / \mathrm{l})$ had an actual influence on quantity of bacteria and environmental fungi incubated on substrate with simazine. Most simazine-resistant bacteria populated activated sludge and biohumus (vermicompost); the biggest strain of resistant fungi was found in floral soil and risosphere soil of maize. Compost and biohumus were the sources of microorganisms which biodegraded simazine, though either of them was the dominant considering the quantity of
\end{abstract}

M. Błaszak $(\bowtie) \cdot$ P. Graczyk

Department of Microbiology and Environmental

Biotechnology, West Pomeranian University

of Technology in Szczecin,

Słowackiego 17,

71-374 Szczecin, Poland

e-mail: Magdalena.Blaszak@zut.edu.pl

R. Pełech

Institute of Chemical Organic Technology, West

Pomeranian University of Technology in Szczecin,

Pułaskiego 10,

70-322 Szczecin, Poland

e-mail: Robert.Pelech@zut.edu.pl simazine-resistant microorganisms. In both cases of periodic culture (microorganisms from biohumus and compost), nearly $100 \%$ of simazine $(50 \mathrm{mg} / \mathrm{l})$ was degraded (within 8 days). After the repeated enrichment culture with simazine, the rate of its degradation highly accelerated, and just after $24 \mathrm{~h}$, the significant decrease of simazine $(20 \%$ in compost and $80 \%$ in biohumus) was noted. Although a dozen attempts of isolating various strains responsible for biodegradation of simazine from compost and biohumus were performed, only the strain identified as Arthrobacter urefaciens (NC) was obtained, and it biodegraded simazine with almost $100 \%$ efficiency (within 4 days).

Keywords Biodegradation -Arthrobacter urefaciens . Simazine $\cdot$ Obsolete pesticide

\section{Introduction}

\subsection{Obsolete Pesticides}

If microorganisms are used to biodegrade sustained, toxic pollutants (persistent organic pollutants) to live organisms (Alexander 1999; Kulkarni and Chaudhari 2006; Nishino and Spain 1993; Oh et al. 2003), it is also possible to exploit them to neutralize organic obsolete pesticides. Nowadays, the use of microorganisms to biodegrade this kind of waste is almost imperceptible, as the most popular way of managing 
with them is thermal utilization (Martínez 2004). There is, in fact, no alternative for high-temperature incineration as it is a popular and fast way of discarding toxic load from the environment, but this technology also bears many drawbacks. Not only the pyrotechnical installations can cause local communities protests but also the high costs of special shipment and, of course, the incineration itself can be an obstacle.

Obsolete pesticides can be shortly defined as stocked pesticides that can no longer be used for their original purpose or any other purpose and therefore require disposal. Such pesticides can no longer be used because their use has been banned, because they have deteriorated, or because they are not suitable for the use originally intended and cannot be used for another purpose, nor can they easily be modified to become usable (FAO 1995). Obsolete pesticides, as well as their preceding utilitarian versions, consist of active substances, that is, chemical compounds or substances which, while penetrating natural environment (waters, soil, food web), modify and harm it, often becoming an ecological time bomb (Egenhofer and Vijgen 2009).

\subsection{Scale of the Problem}

Spreading obsolete pesticides in the environment is a global problem. The scale of the problem varies depending, of course, on economic situation and social awareness. In Western Europe countries (Germany, The Netherlands, Belgium, France) as well as in the Scandinavian countries, pesticide trade and its waste management are strictly under control for years now. In the countries of Central and Eastern Europe and some countries of Latin America (Chile, Venezuela, Nicaragua), the efforts to resolve the pesticide problem legally and effectively seem to bring first results (Egenhofer and Vijgen 2009). Despite the efforts, there are places in these countries particularly burdened with the toxic load, for instance, postproduction pesticides stock "Rudna Góra" Polandabout 160,000 tons of waste on 20 ha, are placed on the list of "Hot Spots" created by Helsinki Commission working on protection of the marine environment of the Baltic Sea (89th place on the list). There are yet places in developing countries where agricultural crops are considerably contaminated with pesticide waste (Ethiopia, Tanzania, Botswana, Mali, Madagas- car) (Dalvie et al. 2006; Martínez 2004; Naidoo and Buckley 2003). Since Poland joined European Union in 2004, the plans of hazardous waste management under European standards have been introduced. The 2010 National Waste Management Plan (Resolution of the Council of Ministers No. 233 from 29 December 2006) establishes, by 2010, elimination of burial grounds and stocks of obsolete pesticides as well as initiation of elimination of hazards caused by environmentally incompliant landfills containing pesticide production wastes. The major obstacle in the plan implementation is not the lack of money, as many undertakings are supported by EU funds, but mostly there are strategy problems and local community protests against pyrotechnic installations in the nearby areas. Currently, two installations for disposal of pesticide waste are operated in Poland, the total combined treatment capacity of which amounts to 6,000 Mg/year (The 2010 National Waste Management Plan-annex to Resolution of the Council of Ministers No. 233 from 29 December 2006)

\subsection{Ways of Utilization}

High-temperature incineration and wastes coprocessing in cement kilns are the most common thermal treatments. There are yet physicochemical treatments: basic catalytic decomposition, gas-phase chemical reduction, and molten salt oxidation. The least popular but yet the most "ecological" method is the biological method called landfarming. The waste landfarming technique involves using the soil's natural, physical, chemical, and biological properties to degrade wastes, with the soil being the treatment media (Martínez 2004).

Biological methods are not only cheaper, but also, regarding the ecological side (the final product of biodegradation are neutral $\mathrm{CO}_{2}, \mathrm{H}_{2} \mathrm{O}$, mineral soles, biomass of microorganisms, thermal energy), they are recommended as environmentally sound. There are, obviously, some limitations of using biological methods as they are time consuming and less efficient comparing to physicochemical methods (Kulkarni and Chaudhari 2006). Technologies based on biological methods of biodegradation of organic pollutants are mostly intended for decontaminating small amounts of chemical substances spread in soil of water. It is the result of limited (notwithstanding) adaptation capability of live organisms taking part in the process of waste degrada- 
tion. It is estimated that $5-10 \%$ concentration of hydrocarbons in substrate is optimal for biodegradation process by specialized culture (Millioli et al. 2009; Zlotnikov et al. 2007). Similar with active substances of pesticides, intensive chemicalization of agroecosystem (or intentional strong contamination of substrate in laboratory) opposes biovariety of organisms, and the scale of destruction of biocoenosis depends evidently on many factors: toxicity and concentration of xenobiotic, the kind of contaminated substrate (natural or laboratorial), climate conditions (or laboratorial conditions), and many more (Lesan and Bhandari 2003; Moreno et al. 2007; Perucci et al. 2000).

\subsection{Biodegradation Abilities of Microorganisms}

Bacteria, actinomycetales (special group of bacteria), and fungi show the biggest capability of degrading pesticides. The species of bacteria and soil fungi distinguishing the strongest activity in degrading pesticides are: bacteria of the genera Arthobacter, Bacillus, Corynebacterium, Flavobacterium, and Pseudomonas; actinomycetales of the genera Nocardia and Streptomyces; and fungi Penicillium, Aspergillus, Fusarium, and Trichoderma (Feakin et al. 1995; Kucharski et al. 2009; Omar and Abdel-Sater 2001; Rousseaux et al. 2001). Kolić et al. (2007), Topp (2001), and Vibber et al. (2007) point out that in their research, the biggest biodegradation potential concerned bacteria Pseudomonas sp. and Nocardioides sp.

Topp (2001) in his extensive work focuses his attention on three, mostly active in the process of biodegrading atrazine (an active triazine herbicide), bacteria. He characterizes bacteria strains, Pseudomonas sp. ADP, Pseudaminobacter sp., and Nocardioides sp., capable of degradation and mineralization of herbicide in soil. These organisms, after putting into soil (bioaugmentation) in the form of pure culture, degraded atrazine in comparable rate. Pseudaminobacter sp. differed, however, as this one used atrazine as the source of carbon only. For other strains, atrazine was both carbon as well as nitrogen source. The author notices the cooperation and reciprocal complementing of the tested microorganisms during the process of mineralization. When put into soil, Pseudaminobacter sp., during hydrolytic dechlorination reaction degrades atrazine to hydroxy atrazine, which becomes substrate in the next reaction, in which Nocardioides sp. takes its part. Resultant cyanuric acid, thanks to the enzymes produced by Pseudomonas sp., evolves into urea, biuret, and $\mathrm{CO}_{2}$. Kolić et al. (2007) proved that at the last stage of atrazine degradation, another bacterium, Ochrobactrum sp., cooperates with Pseudomonas sp.

Vibber et al. (2007), except those characterized by Topp bacteria Nocardioides sp., isolated from the soil Gram-positive bacteria strains of the genus Arthrobacter, which also showed ability to degrade atrazine, however, with much less efficiency. Rousseaux et al. (2001) shows that in the process of degrading atrazine, Gram-negative bacteria, Chelatobacter heintzii, Aminobacter aminovorans, and Stenotrophomonas maltophilia, take part and that they genetically differ from other bacteria by presence of additional gene. According to the author, bacteria and fungi can degrade triazine herbicides through $\mathrm{N}$-dealkylation and dehalogenation. The fungi's ability to degrade xenobiotics relates with the activity of enzymes engaging degradation system of lignin and created on the outside of the cell wall peroxides.

Molecular analyses by PCR of active microorganisms performed by many researchers (Kolić et al. 2007; Vibber et al. 2007; Monard et al. 2008; Rousseaux et al. 2001; Topp 2001) allowed to describe characteristic genes of organisms capable of degrading atrazine and simazine in soil. Genes coding enzymes engaged in the process of degrading these compounds were best characterized in the bacteria strain Pseudomonas sp. Highly conserved genes atzA, $a t z B$, and $a t z C$ are placed on a changeable, big part of plasmid pADP-1 of dimension $108 \mathrm{kbp}$. They take part in first phase of hydrolytic process of atrazine and simazine degradation. They code essential in processes of dechlorination and dealkylation of organic compound hydrolyses. Another part of this plasmid consists of yet less known genes: atzD, atzE, and $a t z F$. They code enzymes taking part in further reactions of transforming intermediate products to $\mathrm{CO}_{2}$ and $\mathrm{NH}_{4}$ (Vibber et al. 2007). The presence of genes $a t z A, a t z B$, and $a t z C$ is also associated with better ability to adapt to a particular environment that directly affects pace and efficiency of the degradation process (Topp 2001). Big quantity of herbicides in soil can be collected and transformed by soil fauna (Green and Obien 1969; Harris and Warren 1964). Monard et al. (2008) report on cooperation between earthworms and soil bacteria in the process of triazine herbicide degradation. 
Substances produced by plants and released to risosphere enhance the activity of microorganisms in this part of a plant that increases the chances and possibilities of xenobiotics degradation. Plant metabolites released to the environment increase microbial resistance to stress factors. The work of Singh et al. (2004) gives analyses of several plant species: Lolium perenne (rye grass), Festuca arundinacae (tall fescue), Pennisetum clandestinum (pennisetum), and Allium sp. (spring onion). It was stated that after a long-termed (80 days) field experience, only pennisetum did not suffer from contamination effects. Nevertheless, the growth of the plant in the atrazine and simazine environment was much slower. After 80 days, the accumulation of both herbicides in soil lowered to $22 \%$. Sweet flag (Acorus calamus) is a type of wetland species. Because of their high growth rate, high level of biomass production, and well-developed rooting systems, where organic compounds can be cached, these species have a great phytoremediation potential. Isolated (by Marecik et al. 2008) from risosphere soil of maize microorganisms, psychrophiles, mesophiles, and fungi showed the ability to degrade atrazine. The biggest degradation rate was observed in fungi (1860\%). Psychrophiles and mesophiles reduced lesser quantity (about 20\%). The most effective at herbicide decomposition were Stenotrophomonas maltophilia and Botrytis cinerea. Positive results can be promising in the process of bioremediation of contaminated lakes and rivers (Marecik et al. 2008).

Biodegradation of obsolete pesticides concerns waste of low biologically active substances content. Retaining evaporation method and composting has practical use. Peat deposits and other organic substances are medium for microorganisms. In such conditions they are selected, and selected strains are capable of degrading xenobiotics (Fogarty and Tuovinen 1991; Omar and Abdel-Sater 2001; Yatmaz and Uzman 2009). There are several mechanisms leading to reducing the remains of pesticides. Washed by rain, they can be absorbed by soil molecules, and they can be oxidized or degraded under UV radiation. They can also be absorbed by plants or animals (Vela et al. 2004; Ralebitso et al. 2002). It seems, however, that biotic transformations connected with soil microorganisms' activity predominate (Marecik et al. 2008). The activity of microorganisms which modifies herbicides activity can proceed various ways which hence lead either to decreasing or increasing their toxicity. Microorganisms can use herbicides as food or energy source or exploit the product of herbicides degradation as biosynthesis of humic acids precursors (Gebendinger and Radosevich 1999; Sánchez et al. 2005).

Elimination of obsolete pesticides which have been stored in burial areas for five decades is a serious ecological problem which demands immediate and systematic solution. With the help of PHARE EU funds, a pilot project on neutralizing obsolete pesticides by utilizing it as substitute fuel in a cement mill was created. The idea of the project is to create foundation for using, on technical scale, the method of pesticides utilization by adding them to substitute fuel used in clinker production in cement mills. This method is suitable for selected pesticides of known composition. The important fact is that during the first analysis, pesticide remains were found neither in fumes nor in products (Stobiecki et al. 2003).

Biotechnological methods allow to recreate natural environment conditions, and they are less expensive and quite often easier as well as more effective (Sánchez et al. 2005). As with petroleum derivatives, there is the possibility of biological utilization of hazardous pesticides on half-technical scale. The example of a company using such measures is Fregata JSC in Gdańsk. As a company focused on board basis market service of pesticide formulation and confection in the process of obsolete pesticides utilization, it uses a biofilter, which is very efficient and effective (500 Mg/year). It should be stressed that this innovative method is safe both for human health and the environment, and therefore, it brings another positive aspect of using it in the near future (The 2010 Pomeranian Waste Management Plan).

The authors of the publication wish to present potential possibilities of using microorganisms in a process of obsolete pesticides disposal. In view of a small number of research performed on this matter, presented data should be understood as an introduction to further planned actions leading to creating microbiological technology of triazine pesticide utilization.

\section{Materials and Methods}

\subsection{Chemical}

Analyses of triazine obsolete pesticide were performed on herbicide Azotop 50 WP containing 
simazine (6-chloro- $N, N^{\prime}$-diethyl-1,3,5-triazine-2,4-diamine) in quantity of $500 \mathrm{~g}$ per $1 \mathrm{~kg}$ of pesticide (it was confirmed with quantity examination with pure model of $98 \%$ simazine); other components of specimen were mineral carrier and surface-active substance. The herbicide was produced by Chemical Plant Organika-Azot S.A., Jaworzno; production date was 1997. License validity date for herbicide was 21 February 2007. This herbicide was withdrawn from turnover due to toxicity for water organisms and big mobility in soil environment (Matyjaszczyk 2008). The material was taken from stock of pesticides of plant breeding station. Herbicide in the form of aqueous suspension (made in sterile conditions) was put into sterile medium. The sterility of herbicidecontaminated medium was checked before each test.

\subsection{Materials}

The sources of bacteria and fungi of potential biodegradation properties were materials of big quantity and variety of microorganisms or materials proposed by the authors of other publications as settled by active microorganisms (Wilson et al. 2000; Marecik et al. 2008; Rousseaux et al. 2001). Before use, the material (except the activated sludge) was passed through a sieve of 2-mm-diameter mesh in order to remove skeletal parts and mechanical impurities. The soils used for isolating microorganisms were:

Risosphere soil of maize from cultivated field near Oder Kostrzyn in Lubuskie Region $\left(52^{\circ} 35^{\prime}\right.$ $\left.18^{\prime \prime} \mathrm{N} ; 14^{\circ} 40^{\prime} 00^{\prime \prime} \mathrm{E}\right)$. It was light clay $(1.3 \%$ of organic carbon; $2.2 \%$ of humus content; $\mathrm{pH} 6.6$ ). Risosphere soil of calamus from coastal area of pond near Oder Kostrzyn in Lubuskie Region $\left(52^{\circ} 35^{\prime} 18^{\prime \prime} \mathrm{N} ; 14^{\circ} 40^{\prime} 00^{\prime \prime} \mathrm{E}\right)$. It was loamy sand of $1.0 \%$ humus content and $0.6 \%$ of organic carbon; pH 7.

Biohumus, Californian earthworms' product produced from manure (vermicompost manure). Organic substances content-28.2\%; pH 7.3.

Strong loamy sand from waterlogged ground of National Park "Ujście Warty" ("Warta Estuary") $\left(52^{\circ} 34^{\prime} 29^{\prime \prime} \mathrm{N}\right.$; 1439'12"E), where extensive cattle pasturage takes place; organic carbon content 9.4\%; humus $16 \%$; pH 5.8 .

Compost vegetable produced during green areas cultivation. The product made by passive com- posting consisted of blades, leaves, and wood chips. To supplement the shortage of nitrogen, urea was added to the plant material. Compost of firm fertilizer's characteristic: $16.5 \%$ organic carbon; pH 7.1.

Floral soil "Blumenerde" Atena Company. Highquality natural organic substrate produced from peat, enriched with the necessary growth and development of plant macro- and microelements. The substrate recommended for cultivation of plants of medium food demands in housing conditions; $\mathrm{pH} 5.5$.

Activated sludge from mechanical and biological sewage treatment facility in Slupsk $\left(54^{\circ} 29^{\prime} 28^{\prime \prime} \mathrm{N}\right.$; $\left.17^{\circ} 01^{\prime} 42^{\prime \prime} \mathrm{E}\right)$. During the performed processes, redaction of contamination load takes place: BZT5 in quantity of $99.2 \%$, ChZT in $96.7 \%$, organic phosphorus in $96.7 \%$, organic nitrogen in $88.4 \%$, and suspension in $97 \%$.

\subsection{Methods}

Investigation scheme:

1. The search for biotopes rich in simazine-resistant microorganisms

2. The search for biotopes consisting of simazinedegrading microorganisms

3. Active microorganisms isolation, identification, and culture

In order to determine statistically relevant influence of simazine on quantity of bacteria and fungi and to distinguish statistically important differences in simazine content in culture media during their growth, one and multiple variance and Tukey's test of multiple comparison were performed at the significance level of 0.05 (StatSoft, Inc., 2007).

\subsubsection{The Search for Biotopes Rich in Simazine- Resistant Microorganisms}

Bacterial heterotrophes were cultured on agar enriched with (grams per liter): peptone, $4.0 \mathrm{~g} / 1$; meat extract, $0.4 \mathrm{~g} / \mathrm{l}$; enzymatic casein hydrolysate, $5.4 \mathrm{~g} / \mathrm{l}$; yeast hydrolysate, $1.7 \mathrm{~g} / \mathrm{l} ; \mathrm{NaCl}, 3.5 \mathrm{~g} / \mathrm{l}$; and agar, $10.0 \mathrm{~g} / 1$ (made by BioCorp Company). Fungi where cultured on Rose Bengal medium with streptomycin (Martin 1950), in grams per liter: $\mathrm{KH}_{2} \mathrm{PO}_{4}, 1 \mathrm{~g} / \mathrm{l}$; 
$\mathrm{MgSO}_{4}, 0.5 \mathrm{~g} / \mathrm{l}$; glucose, $10.0 \mathrm{~g} / \mathrm{l}$; peptone, $5.0 \mathrm{~g} / \mathrm{l}$; agar, $20.0 \mathrm{~g} / \mathrm{l}$; and Rose Bengal, $0.035 \mathrm{~g} / \mathrm{l}$. To both growth media, right before putting it on Petri dishes, aqueous suspension Azotop 50 WP (only sterile distilled water was used) was added in two doses to obtain the simazine content in culture medium equal to $50 \mathrm{mg} / \mathrm{l}$ (I dose) and $100 \mathrm{mg} / \mathrm{l}$ (II dose). To sterile Petri dishes, $1 \mathrm{~cm}^{3}$ of aqueous solution obtained from diluting assessed materials (for bacteria, $10^{-4}, 10^{-5}$, and $10^{-6}$; for fungi, $10^{-3}, 10^{-4}$, and $10^{-5}$ ) was added, and then the dishes were filled with substrate carefully mixed with the pesticide. Control medium was the one the pesticide was not put into and to which the microorganisms' growth on contaminated medium was compared. All materials inoculations were performed in four repetitions. Before each use of the medium with pesticide, the barrenness was tested by putting it on sterile Petri dishes - in neither case the growth of microorganisms was found. Cultures were incubated in the temperature of $25^{\circ} \mathrm{C}$ for 3 days (bacteria) and 7 days (fungi). After this time, both in control medium and contaminated medium, bacteria and fungi colonies were summed up by the means of electronic colony counter and the number of units forming a colony was given (colony-forming units (CFU) per gram).

\subsubsection{The Search for Biotopes Consisting of Simazine- Degrading Microorganisms}

Biological substance was put into physiologic saline $\left(10^{-4}\right)$. Such dilution contained approximately (depending on the object) $10^{6}-10^{7}$ microorganisms cells in $1 \mathrm{ml}$. Soil dilution was put into sterile mineral medium Bushnell-Haas Broth, (1:10), modified by exchanging nitrogen and carbon source (in grams per liter: $\mathrm{MgSO}_{4}, 0.2 \mathrm{~g} / 1 ; \mathrm{CaCl}_{2}, 0.02 \mathrm{~g} / 1 ; \mathrm{KH}_{2} \mathrm{PO}_{4}, 1.0 \mathrm{~g} / \mathrm{l}$; $\mathrm{FeCl}_{3}, 0.05 \mathrm{~g} / \mathrm{l} ; \mathrm{C}_{6} \mathrm{H}_{5} \mathrm{Na}_{3} \mathrm{O}_{7}, 1.0 \mathrm{~g} / \mathrm{l}$; and Azotop 50 $\mathrm{WP}, 50.0 \mathrm{mg}$ simazine per liter). Experiments were performed in Erlenmeyer flask containing $250 \mathrm{ml}$ of mineral salts medium. Samples were incubated at $20^{\circ} \mathrm{C}$ and shaken at $150 \mathrm{rpm}$ for several days in the dark. The culture was performed in two repetitions.

Content of simazine in breeding was measured once per $24 \mathrm{~h}$. Simazine concentration in breeding was indicated with a method of gas chromatography. ThermoElectron Trace Ultra gas chromatograph was used. Analyses were conducted at following conditions: RTX-5 (RESTEK) capillary column, $30 \mathrm{~m} \times$
$0.53 \mathrm{~mm} \times 1.5 \mu \mathrm{m}$, helium carrier gas, $5 \mathrm{~cm}^{3} / \mathrm{min}$, FID detector $280^{\circ} \mathrm{C}$, sample injector $280^{\circ} \mathrm{C}$, bake temperature program at $200^{\circ} \mathrm{C}$ for $4 \mathrm{~min}$, and then accretion of $10^{\circ} \mathrm{C} / \mathrm{min}$ until $220^{\circ} \mathrm{C}$.

Simazine isolation from matrix (soil solution) was made by using the method of liquid-liquid extraction. Dichloromethane was used as an extraction solvent. Quantitative determinations were conducted with internal standard method. As an internal standard, 1bromonapthalene was taken. Concentration of 1bromonapthalene was established on $20 \mathrm{mg} / \mathrm{l}$. To make the analysis, $1 \mathrm{ml}$ of the examined solution was placed into the weighted polypropylene conic vial with $2 \mathrm{ml}$ volume. After the solution was weighted, $0.5 \mathrm{ml}$ of dichloromethane solution of 1-bromonaphtalene was added. The content of the vial was shaken for $10 \mathrm{~min}$. When the phases were separated, dichloromethane phase was analyzed.

Simazine concentrations based on peak areas obtained earlier were calculated from the equation below:

$C_{\mathrm{s}}=\left(A \cdot \frac{S_{\mathrm{s}}}{S_{\mathrm{w}}}+B\right) \cdot C_{\mathrm{w}} \cdot \frac{m_{\mathrm{e}}}{m_{\mathrm{r}}}$,

where $A$ and $B$ are correction factors, $C_{\mathrm{s}}$ and $C_{\mathrm{w}}$ are simazine and standard concentrations (milligrams per liter), and $m_{\mathrm{e}}$ and $m_{\mathrm{r}}$ are masses of extraction solvent and examined solution (grams).

Correction factors were established by proportioning series of solutions with known concentrations onto the chromatograph system.

The description obtained was presented below (Fig. 1). On the basis of the characteristic course, coefficients $A=1.2881$ and $B=0.7699$ were established. Average relative error of the method equals $11 \%$. Average relative error of the method was calculated from the equation:

$\bar{\delta}=\frac{1}{N} \cdot \sum\left(\frac{C_{\mathrm{i}}^{0}-C_{\mathrm{i}}}{C_{\mathrm{i}}^{0}}\right)$,

where $C_{\mathrm{i}}$ and $C_{\mathrm{i}}^{0}$ are measured and expected values of simazine concentration and $N$ is the measurement number.

\subsubsection{Active Microorganism Isolation, Identification, and Culture}

From mixed culture obtained from previous phase (on Bushnell-Haas Broth medium with simazine), in which 


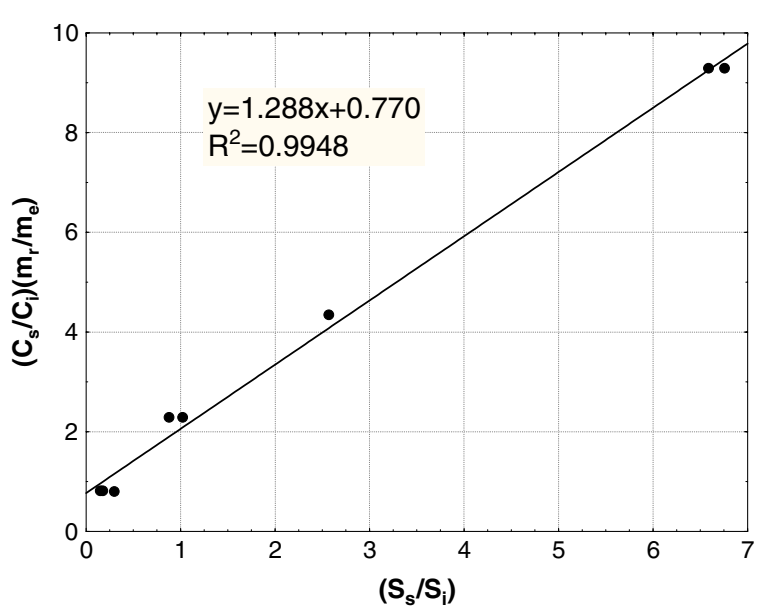

Fig. 1 Calibration curve of simazine. $C_{\mathrm{s}}$ and $C_{\mathrm{i}}$ are simazine and internal standard (1-bromonaphtalene) concentration (milligrams per liter), $m_{\mathrm{e}}$ and $m_{\mathrm{r}}$ are masses of extraction solvent and examined solution (grams), and $S_{\mathrm{s}}$ and $S_{\mathrm{i}}$ are simazine and internal standard peak area

simazine biodegradation was affirmed, microorganisms were isolated. Breeding material was inoculated on enriched agar (description above) and on Thayer-Martin medium (description above), both mediums were simazine $(50 \mathrm{mg} / \mathrm{l})$ contaminated. Separate isolates which grew as bacteria and fungi colonies were proliferated on solid substrate (enriched agar and Martin medium) using reduction inoculation (for bacteria) and deep-seated inoculation (for fungi), and then biological material was placed into physiologic saline in condition of orbital shaker at $150 \mathrm{rpm}$. The biological material put into physiologic saline was collected and placed in sterile mineral medium Bushnell-Haas Broth, $\left(7 \times 10^{8}\right.$ CFU per $1 \mathrm{ml})$, modified by exchanging nitrogen and carbon source (in grams per liter: $\mathrm{MgSO}_{4}, 0.2 \mathrm{~g} / \mathrm{l}$; $\mathrm{CaCl}_{2}, 0.02 \mathrm{~g} / \mathrm{l} ; \mathrm{KH}_{2} \mathrm{PO}_{4}, 1 \mathrm{~g} / \mathrm{l} ; \mathrm{FeCl}_{3}, 0.05 \mathrm{~g} / \mathrm{l}$; $\mathrm{C}_{6} \mathrm{H}_{5} \mathrm{Na}_{3} \mathrm{O}_{7}, 1.0 \mathrm{~g} / \mathrm{l}$; and Azotop $50 \mathrm{WP}, 50 \mathrm{mg}$ simazine per liter). Experiments were performed in Erlenmeyer flask containing $250 \mathrm{ml}$ of mineral salts medium. Samples were incubated at $20^{\circ} \mathrm{C}$ and shaken at $150 \mathrm{rpm}$ for several days in the dark. Microorganisms responsible for simazine biodegradation were sought. Dozen bacterial isolates and several fungal isolates were tested on simazine biodegradation. Simazine content was surveyed with gas chromatography method every $24 \mathrm{~h}$. Bacteria showing biodegradation activity were genetically analyzed to determine the microorganisms' affinity.

Strains were identified by molecular technique (16S ribosomal DNA). Exponentially growing cells
$(1 \mathrm{ml})$ were harvested from the cultivation media for extraction of genomic DNA. Extraction procedure was done with Genomic Mini Kit (A\&A Biotechnology, Poland) according to the instruction of the manufacturer. The purified DNA was used as template in the PCR. The 16S rRNA gene was amplified with the 27 forward primer and the reverse primer 1492 (Lane 1991). The PCR product was purified and cloned into the pJet1 vector (Fermentas MBI, Lithuania) according to the instruction of the manufacturer. Two purified plasmids of each of the strains with expected length of the insert were sequenced. The 16S rRNA gene sequence of isolates was aligned against the selected sequences available in the public databases - the GenBank database (Altschul et al. 1990). This research was repeated twice.

\section{Results and Discussion}

\subsection{Active Strains in Simazine Biodegradation}

Results of this work can be compared to the results of many other works concerning pesticides' influence on microorganisms (their quantity, metabolic activity, soil organisms, enzymes) as well as with the results of works concerning mechanisms of active pesticides degradation. However, the authors of this publication did not find in the research database any publication regarding the use of biodegradation to utilize obsolete pesticides, but only the premises of potential possibilities of such technologies seem to appear in some works.

The experiment scheme was to determine which of the biocoenoses (floral soil, farming soil, organic fertilizer, and activated sludge were tested) are rich in microorganisms that are simazine resistant, and then the materials consisting of such microorganisms were analyzed on microorganisms biodegrading simazine content. The last stage was the isolation of bacteria and fungi strains responsible for biodegradation. Tracing particular active strains from dozen repeatedly examined was difficult. Only one bacteria strain showed interchangeable positive result. Genetic analysis proved, with the accuracy up to $99 \%$, that the isolated strain is Arthrobacter urefaciens NC (Fig. 2).

Bacteria of the Arthrobacter genus were frequently recognized as good at $s$-triazine herbicide biodegradation. Rousseaux et al. (2001) isolated from atrazine- 
Fig. 2 Simazine biodegradation by Arthrobacter urefaciens strain $\mathrm{NC}$

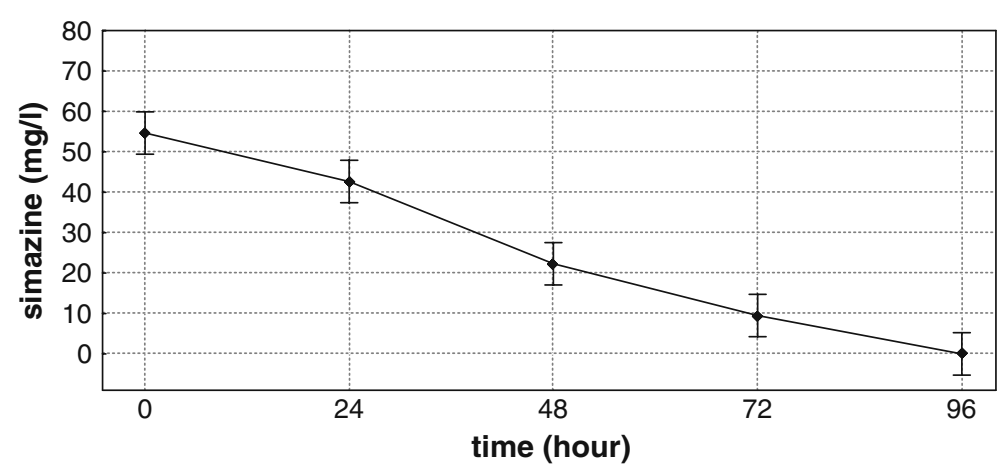

contaminated soil Arthrobacter crystallopoietes strain, which when cultivated on mineral medium for 2 weeks reduced the quantity of xenobiotic from the substrate to about $90 \%$. Other tested strains (e.g., Chelatobacter sp.) biodegraded with less efficiency (about 60\% subsidence). Test results presented by Kolić et al. (2007) in his work were interesting, for depending on modification of substrate composition, different atrazine (Arthrobacter sp.) biodegradation level was obtained. When atrazine was the only source of nitrogen and carbon, the reduction was about $50 \%$, and after adding citrate and ammonium salts to medium, the bacteria reduced atrazine in nearly $100 \%$. It was proved that for Arthrobacter sp. and Arthrobacter keyseri, atrazine was the source both of carbon and nitrogen. Topp (2001) and Monard et al. (2008) describe bacteria of Pseudomonas strains particularly active in atrazine biodegradation. Atrazine inoculated to Pseudomonas-inhabited soil was decomposed in several dozen days. The mineralization rate of $s$-triazine herbicides depends on environmental factors, which was proved by Kodama et al. (2001). Changing the substrate reaction and incubation temperature, he determined optimal parameters of simazine biodegradation for Penicillium steckii and Moraxella ovis. In case of fungi, best were: $\mathrm{pH} 7-8$, $30^{\circ} \mathrm{C}$, and traces of glucose and yeast extract in substrate (over 50\% subsidence of simazine in 5 days); in case of bacteria: $\mathrm{pH} 5$ and $35^{\circ} \mathrm{C}$ (reduction 60 $100 \%$ ). Klebsiella planticola degraded simazine in about $70 \%$ in 20 days, and it was observed that the bigger the dose of simazine in culture (on membrane lipid fatty acid), the higher the level of utilization is. Furthermore, it was proven that cyanuric acid and urea are also the products of the utilization process (Sánchez et al. 2005). Nearly $100 \%$ of simazine was degraded after 40 days of incubation of mixed bacteria culture (therein Arthrobacter sp.) in bioreactor. It was found that $s$-triazine herbicides were used by microorganisms both as a carbon and nitrogen source (Mondragon-Parada et al. 2008). All of these experiments together with our tests results as well as many others show the possibility of using properly assorted microorganisms populations to the process of contaminated systems biodegradation.

In the presented work, bacteria strain having fundamental impact on biodegradation of simazine added to culture media in concentration of $50 \mathrm{mg} /$ 1 was isolated. The bacteria were taken from compost, where chromatographic analysis showed essential herbicide subsidence. During periodic cultivation, the survey was taken every $24 \mathrm{~h}$ and showed that the strain-Arthrobacter urefaciens strain $\mathrm{NC}-$ quickly degraded simazine. After 96 h, nearly 100\% of herbicide subsidence was obtained (Fig. 2).

However, before determining which microorganism is responsible for simazine biodegradation, the search for material (among soils, organic fertilizer, and activated sludge) rich in bacteria and fungi that are pesticide resistant was performed.

\subsection{Growth of Environmental Microorganisms on Simazine}

The reaction of microorganisms inhabiting tested objects depended on applied simazine dose. Generally, the dose $50 \mathrm{mg} / \mathrm{l}$ did not, in most cases, cause statistically important changes in microorganisms' quantity, whereas the dose of $100 \mathrm{mg} / \mathrm{l}$, in most cases, vitally stimulated their growth and only occasionally decreased their quantity (Table 1). Differential results were also observed in the extensive work of Moreno et al. (2007) where the series of atrazine doses was put into soil. The authors 
observed, in some cases (with smaller doses), growth of microorganisms' biomass quantity with simultaneous pesticide subsidence form soil. However, the pesticide's effect depended on the dose and the measurement period. Both microorganisms' biomass quantity and other microbiological parameters $\left(\mathrm{CO}_{2}\right.$ emission, ATP content, dehydrogenase) were inconsistent. Alike in the work of Martínez-Toledo et al. (1998), the effect of pesticide influence on bacteria and fungi quantity was diverse and depended on the dose and measurement period.

In the presented work, the biggest number of simazine-resistant bacteria inhabited activated sludge and biohumus, and the least numerous ones inhabited floral soil, risosphere soil of maize, and compost (taking into account the average number of both doses) (Table 1). The most numerous population of simazine-resistant fungi inhabited floral soil and risosphere soil of maize while the least of them were in biohumus and activated sludge (taking into account the average number of both doses) (Table 1).

Pesticide-microorganism interaction is bidirectional interaction. Microorganisms metabolize pesticides, but also pesticides influence the quantity and population content of microorganisms and therefore the direction and dynamics of biochemical processes they perform. Changes of cells' metabolism direction are connected with inactivation or activation of particular enzymes. Pesticides periodically stop some processes whereupon the state of equilibrium returns. The consequence of this dependence is biological variety limitation, and associated with it are quality and quantity of microorganisms' composition of soil (Lesan and Bhandari 2003; Moreno et al. 2007; Perucci et al. 2000).

Under the influence of pesticides, the activity of some groups of soil microorganisms is delayed with simultaneous stimulation of others. As Różański (1992) states, it is related with selection and adaptation of microorganisms phenomenon. According to the author, the organisms of the highest adaptive properties are fungi. They demonstrate the ability to hydrolyze toxic compounds in which the decomposition products are used for their own food and energy needs. Using organic substances from chemical plant protection products and products of dead cells of sensitive specimen, they are able to live and reproduce. Fungi inhabiting objects tested in this work were resistant to simazine-active substance contained in commercial product Azotop 50 WP. What is more, after adding herbicide to medium (especially the dose $100 \mathrm{mg} / \mathrm{l}$ ), in most cases, the vital quantity increase was observed. Different observations had been reported by Przybulewska and Taborska (2008). Here, all applied triazine herbicide efficiently decreased the number of fungi. Their subsidence reached up to $60 \%$ compared with control.

Biological imbalance in soil, being the effect of pesticide activity, is the consequence of various resistant levels of particular microbial species to these products, used doses, and soil environment condi-

Table 1 Bacteria and fungi quantities in the solid medium culture with and without simazine

\begin{tabular}{|c|c|c|c|c|c|c|}
\hline \multirow[t]{3}{*}{ Object's symbol } & \multirow{2}{*}{\multicolumn{3}{|c|}{$\frac{\text { Bacteria }\left[\mathrm{CFU} \times 10^{4}\right]}{\text { Simazine dose }[\mathrm{mg} / \mathrm{l}]}$}} & \multicolumn{3}{|c|}{ Fungi $\left[\mathrm{CFU} \times 10^{3}\right]$} \\
\hline & & & & & & \\
\hline & 0 & 50 & 100 & 0 & 50 & 100 \\
\hline 1 & $81.26 \mathrm{a}$ & $86.71 \mathrm{a}$ & $45.50 \mathrm{~b}$ & $26.22 \mathrm{~B}$ & $29.77 \mathrm{AB}$ & $31.20 \mathrm{~A}$ \\
\hline 2 & $979.36 \mathrm{a}$ & $954.18 \mathrm{a}$ & $597.41 \mathrm{~b}$ & $45.07 \mathrm{~A}$ & $47.84 \mathrm{~A}$ & $36.95 \mathrm{~B}$ \\
\hline 3 & $61.51 \mathrm{~b}$ & $60.66 \mathrm{~b}$ & $92.26 \mathrm{a}$ & $20.13 \mathrm{~A}$ & $18.52 \mathrm{~A}$ & $17.71 \mathrm{~A}$ \\
\hline 4 & $214.88 \mathrm{~b}$ & $196.95 \mathrm{c}$ & $333.01 \mathrm{a}$ & $38.18 \mathrm{~A}$ & $33.45 \mathrm{~A}$ & $40.09 \mathrm{~A}$ \\
\hline 5 & $2683.66 \mathrm{~b}$ & $1998.74 \mathrm{c}$ & $3487.86 \mathrm{a}$ & $1813.50 \mathrm{~A}$ & $2170.10 \mathrm{~A}$ & $906.75 \mathrm{~B}$ \\
\hline 6 & $106.21 \mathrm{a}$ & $102.66 \mathrm{a}$ & $42.49 \mathrm{~b}$ & $158.93 \mathrm{C}$ & $223.96 \mathrm{~B}$ & $286.01 \mathrm{~A}$ \\
\hline 7 & $99.50 \mathrm{~b}$ & $111.25 \mathrm{~b}$ & $199.00 \mathrm{a}$ & $87.25 \mathrm{~A}$ & $81.00 \mathrm{~A}$ & $78.53 \mathrm{~A}$ \\
\hline
\end{tabular}

Values followed by different letters within a row (separately for bacteria and for fungi) are significantly different at $5 \%$ level based on Tukey's test

Description of objects from which the microorganisms were taken: 1 risosphere of maize, 2 risosphere of calamus, 3 biohumus, 4 strong loamy sand, 5 compost, 6 floral soil, 7 activated sludge 
tions. Herbicides applied in small doses in agriculture do not usually have a detrimental impact on soil microorganisms. Not only the kind and dose of herbicide formulation but also its persistency in soil can have a big significance for the biology of the environment. What is more, the toxicity of herbicides towards microbes can also depend on composition and $\mathrm{pH}$ of the substrate. Herbicides' influence on the development of microorganisms depends on properties of tested soil as well. Soils high in organic matter and therefore with high sorption capacity are inhabited by pesticide-resistant microorganisms (Martínez-Toledo et al. 1998; Różański 1992). However, our own test results do not prove those reports. The highest sensitivity was showed by bacteria from floral soil and compost. The last of listed objects, although high content of organic substances, responded with population decline after simazine was added. Similar case was noted with fungi. Resistance of this group of microorganisms dominated in biohumus, which contained $28.2 \%$ of organic substance. Some herbicides can change in soil into toxic substance which selects microbes. Sandy soils react on added herbicide much quicker than fertile soil rich in organic compounds. After fertilizing soil with organic substance, partial activity protection against herbicide effect takes place. Triazine herbicides easily bind with humus acids and as well as hardly degradable compounds; they degrade faster in soil rich in microbes (Różański 1992). This is confirmed by this work results that among all tested objects, only the microorganisms inhabiting biohumus and compost really influenced the process of simazine biodegradation. It has to be noted that the objects in respect to other ones had the highest quantity of organic substance. The highest the pesticides bind with compost ingredients, the lowest its biological activity is. Atrazine can join hydrogenous and ionic bondings with organic matter and loamy minerals, and therefore, the content of these compounds in soil has a huge importance during the herbicide degradation (Alva and Singh 1990; Lesan and Bhandari 2003; Ralebitso et al. 2002). Green and Obien (1969) and Harris and Warren (1964) report that pesticides flushed by rain are absorbed by soil particles where they can undergo oxidation or disintegrate under the influence of UV radiation and that they can also be taken up by plants and animals. It seems, however, that biotic trans- formations related to soil microorganisms' activities dominate over others (Barriuso and Houot 1996).

\subsection{Simazine Degradation by Environmental Microorganisms}

The sources of simazine-biodegrading microorganisms were compost and biohumus; both these objects (no. 3 and no. 5) did not dominate in the number of simazine-resistant microbes (Table 1). In both cases of periodic culture, nearly $100 \%$ of simazine (from $50 \mathrm{mg} / \mathrm{l}$ ) was degraded (Table 2). After reintroduction of simazine to culture medium $(50 \mathrm{mg} / \mathrm{l})$, the simazine decline rate highly accelerated. Only the first chromatographic analysis (after $24 \mathrm{~h}$ ) showed significant $(20 \%$ in case of compost and $80 \%$ in case of biohumus) simazine decrease (Table 3).

In the presented work, the influence of microorganisms inhabiting risosphere soil of maize (object no. 1) and risosphere soil of calamus (object no. 2) on simazine biodegradation was examined. Unfortunately, the obtained results of inability to biodegrade of most microorganisms of analyzed objects (objects nos. 1, 2, 4, 6, and 7) did not confirm reports of other researchers. Singh et al. (2004) analyzed risosphere of several plant species: rye grass, tall fescue, pennisetum, and spring onion. After long-termed (80 days) field experiment, it was found that only pennisetum did not show toxicological symptoms. However, the growth of the plant in conditions of atrazine and simazine contamination was much slower. After 80 days, the concentration of both herbicides in soil declined to $22 \%$. The authors of this work also notice other plants' potential, including maize and kochia. Marecik et al. (2008) isolated from risosphere soil of calamus microorganisms - psychrophiles, mesophiles, and fungi, which showed the capability of atrazine degradation. The biggest level of degradation was noticed in fungi (18-60\%). Psychrophiles and mesophiles reduced lesser quantity (about 20\%).

Grabińska-Sota et al. (2000) performed experiments on pesticides' influence on activated sludge work. She observed then that only after several days from introducing herbicide formulation (Chwastox extra $300 \mathrm{SL}$ ) to activated sludge, the effect of decontamination worsened. However, over time, the increase of the compound decomposition was noted. The author suggests that initial abiotic processes 
Table 2 Abilities to biodegrade simazine by microorganisms inhabiting objects

Values followed by different letters within a row are significantly different at 5\% level based on Tukey's test

1 risosphere of maize, 2 risosphere of calamus, 3 biohumus, 4 strong loamy sand, 5 compost, 6 floral soil, 7 activated sludge
Simazine $[\mathrm{mg} / \mathrm{l}]$

\begin{tabular}{llllllll}
\hline Object's symbol & \multicolumn{7}{l}{ Time [hours] } \\
\cline { 2 - 7 } & \multicolumn{1}{l}{24} & 48 & 72 & 96 & 144 & 192 \\
\cline { 2 - 8 } & $50.2 \mathrm{a}$ & $52.1 \mathrm{a}$ & $54.2 \mathrm{a}$ & $52.0 \mathrm{a}$ & $52.7 \mathrm{a}$ & $50.4 \mathrm{a}$ & $50.9 \mathrm{a}$ \\
2 & $42.4 \mathrm{a}$ & $40.5 \mathrm{a}$ & $39.0 \mathrm{a}$ & $43.7 \mathrm{a}$ & $40.9 \mathrm{a}$ & $40.6 \mathrm{a}$ & $35.9 \mathrm{a}$ \\
3 & $46.8 \mathrm{a}$ & $42.7 \mathrm{a}$ & $42.3 \mathrm{a}$ & $43.6 \mathrm{a}$ & $9.5 \mathrm{~b}$ & $7.4 \mathrm{~b}$ & $4.8 \mathrm{~b}$ \\
4 & $57.0 \mathrm{a}$ & $65.1 \mathrm{a}$ & $54.3 \mathrm{a}$ & $57.8 \mathrm{a}$ & $60.1 \mathrm{a}$ & $60.6 \mathrm{a}$ & $56.4 \mathrm{a}$ \\
5 & $59.3 \mathrm{a}$ & $59.5 \mathrm{a}$ & $60.6 \mathrm{a}$ & $52.2 \mathrm{a}$ & $57.2 \mathrm{a}$ & $42.5 \mathrm{~b}$ & $10.1 \mathrm{c}$ \\
6 & $57.4 \mathrm{a}$ & $55.9 \mathrm{a}$ & $57.7 \mathrm{a}$ & $49.1 \mathrm{a}$ & $52.7 \mathrm{a}$ & $56.3 \mathrm{a}$ & $52.9 \mathrm{a}$ \\
7 & $55.0 \mathrm{a}$ & $55.6 \mathrm{a}$ & $60.7 \mathrm{a}$ & $52.5 \mathrm{a}$ & $54.1 \mathrm{a}$ & $56.4 \mathrm{a}$ & $57.4 \mathrm{a}$ \\
\hline
\end{tabular}

gradually gave place to microbiological ones. However, the impact of microorganisms of activated sludge on biodegrading simazine assessment conducted in the work did not indicate the significance of the impacts. In the presented work, the author did not find the presence of simazine-biodegrading microorganisms. After $96 \mathrm{~h}$ of the process, the obtained result, including method error, was comparable with the first survey $(58 \mathrm{mg} / \mathrm{l})$.

After reapplication of simazine to mixed culture, obtained from compost and biohumus (objects nos. 3 and 5), it occurred that both in biohumus and in compost multiplied, resistant to described stress factor biomass of microbes had a good impact on simazine disappearance. Only first chromatographic analysis (after $24 \mathrm{~h}$ ) showed significant herbicide reduction (Table 3).

Determining the resistance of microorganisms inhabiting triazine substance-contaminated soils, Przybulewska and Taborska (2008) proved that all used triazine pesticides vitally increased the number of bacteria, even to $300 \%$ compared to control

Table 3 Capability of simazine biodegradation of microorganisms inhabiting objects after simazine reapplication

Simazine $[\mathrm{mg} / \mathrm{l}]$

Object's symbol Time [hours]

\begin{tabular}{rrrrrr}
\cline { 3 - 6 } 3 & 192 & 216 & 240 & 264 & 288 \\
\cline { 2 - 6 } 5 & $52.2 \mathrm{a}$ & $12.6 \mathrm{~b}$ & $10.1 \mathrm{~b}$ & $9.5 \mathrm{~b}$ & $4.2 \mathrm{c}$ \\
& $45.0 \mathrm{a}$ & $34.7 \mathrm{~b}$ & $15.2 \mathrm{c}$ & $10.6 \mathrm{c}$ & $6.3 \mathrm{c}$ \\
\hline
\end{tabular}

Values followed by different letters within a row are significantly different at 5\% level based on Tukey's test

3 biohumus, 5 compost medium. They also noticed that each, used for decades, triazine product induced occurrence of microorganisms resistant to other herbicides from a group. Różański (1992) explains it by microorganisms' strengthened pesticide resistance easily noticeable after replicating xenobiotic to the same soil.

Although in the intensive trials, dozen isolates from biohumus and compost were obtained and tested for biodegradational capabilities, only one bacteria strain, Arthrobacter urefaciens strain NC, gave positive results in each repetition. Another promising bacteria Sinorhizobium morelense (98\% of conformity) did not give the unequivocal result-for ten repetitions (culture on Bushnell-Haas Broth substrate with simazine), up to eight times the biodegradational activity was not confirmed.

\section{Conclusion}

Beginning the experiment, it was assumed that the research material rich in simazine-resistant microorganisms (the number of resistant bacteria and fungi in each object was determined) would also be the source of biodegrading strains. The results did not prove the expectations unequivocally. Compost was the habitat of intensively biodegrading microbes (about $80 \%$ of simazine subsidence per week) but was not distinguished with bigger quantity of simazine-resistant microorganisms; what is more, compost bacteria were particularly sensitive, even on a smaller dose of simazine $(50 \mathrm{mg} / \mathrm{l})$. Nonetheless, after reapplying the dose of simazine to compost microbes' culture, $25 \%$ of simazine was degraded only during the first $24 \mathrm{~h}$ of incubation. 
Another situation regarded biohumus, which was characterized by a big quantity of simazine-resistant bacteria, or even the number of bacteria from compost with simazine to be larger than that from control medium. The fact had also its reflection in biodegradational activity of these microorganisms, which after 1 week of incubation degraded over $90 \%$ of simazine, and only 1 day after reapplication, the simazine quantity was five times lesser than at the beginning of the test. Simazine stimulated the growth of bacteria from activated sludge. The bigger dose was used, the more bacteria were found on this substrate (compared with the control medium without simazine); however, in this material, microorganisms ready to simazine biodegradation were not found.

Concluding, it can be said that simazine influence on bacteria and fungi quantities depended on the dose of simazine. Generally, it can be presented that the dose of $50 \mathrm{mg}$ did not vitally influence microorganisms' quantity, while the dose of $100 \mathrm{mg}$ simply enlarged their number, except of course, less numerous cases where the growth inhibition took place - of bacteria (from floral soil and risosphere soil of calamus) and of fungi (biohumus, activated sludge).

Although there were several trials of isolating strains responsible for simazine biodegradation from mixed cultures from biodegradational activity objects, only one strain was obtained. This isolate is Arthrobacter urefaciens strain NC $(99 \%$ of conformity), which in several repetitions, invariably and exponentially, biodegraded simazine with nearly $100 \%$ efficiency.

Surprising biodegradational productivity (80$100 \%$ ) and the fast rate of the process (4-14 days) are very promising concerning further experiments aiming to contrive the method of biological utilization of simazine. The author of this publication, under the research funded by the Polish Department of Science, is to proceed with further extended studies on this, so far, little considered alternative for obsolete pesticide utilization.

Open Access This article is distributed under the terms of the Creative Commons Attribution Noncommercial License which permits any noncommercial use, distribution, and reproduction in any medium, provided the original author(s) and source are credited.

\section{References}

Alexander, M. (1999). Bioremediation technologies: in situ and solid phase. In Biodegradation and bioremediation (pp. 159-176). San Diego: Academic Press.

Altschul, S. F., Gish, W., Miller, W., Myers, E. W., \& Lipman, D. J. (1990). Basic local alignment search tool. Journal of Molecular Biology, 215, 403-410.

Alva, A. K., \& Singh, M. (1990). Effects of soil-cation composition on reaction of four herbicides in a candler fine sand. Water, Air, and Soil Pollution, 52, 175-182.

Barriuso, F., \& Houot, S. (1996). Rapid mineralization of $s$-triazine ring of atrazine in soil in relation to soil management. Soil Biology \& Biochemistry, 28, 13411348.

Dalvie, M. A., Africa, A., \& London, L. (2006). Disposal of unwanted pesticides in Stellenbosch, South Africa. Science of the Total Environment, 361, 8-17.

Egenhofer, C., \& Vijgen, J. (2009). Obsolete pesticides: a ticking time bomb and why we have to act now. Energy CEPS Special Reports. Brussels: CEPS.

FAO. (1995). Pesticide disposal, series 2. Prevention of accumulation of obsolete pesticide stocks. Provisional guidelines of the United Nations (FAO) under project GCP/INT/572/NET: "Prevention and Disposal of Unwanted Pesticide Stocks in Africa and the Near East". FAO pesticide disposal series. FAO, Rome

Feakin, S. J., Blackburn, E., \& Burns, R. G. (1995). Inoculation of granular activated carbon in a fixed bed with $s$-triazinedegrading bacteria as a water treatment process. Water Research, 29(3), 819-825.

Fogarty, A. M., \& Tuovinen, O. H. (1991). Microbiological degradation of pesticides in yard waste composting. Microbiological Reviews, 55(2), 225-235.

Gebendinger, N., \& Radosevich, M. (1999). Inhibition of atrazine degradation by cyanazine and exogenous nitrogen in bacterial isolate M91-3. Applied Microbiology and Biotechnology, 51, 375-381.

Grabińska-Sota, E., Kalka, J., Wiśniowska, E., \& Ścieranka, B. (2000). Wpływ wybranych pestycydów na pracę osadu czynnego (The influence of pesticides on the activated sludges work). Ochrona Środowiska, 2(77), 39-43.

Green, R. E., \& Obien, S. R. (1969). Herbicide equilibrium in soil in relation to soil water content. Weed Science, 17(4), 514-519.

Harris, C. I., \& Warren, G. F. (1964). Adsorption and desorption of herbicides by soil. Weeds, 12(2), 120-126.

Kodama, T., Ding, L., Yoshida, M., \& Yajima, M. (2001). Biodegradation of an $s$-triazine herbicide, simazine. Journal of Molecular Catalysis B: Enzymatic, 11, 10731078.

Kolić, N. U., Hrasak, D., Begonia, A. K., Petrić, I., Stipicevic, S., Soulas, G., et al. (2007). Combined metabolic activity within an atrazine-mineralizing community enriched from agrochemical factory soil. International Biodeterioration and Biodegradation, 60, 299-307.

Kucharski, J., Baćmaga, M., \& Wyszkowska, J. (2009). Effect of soil contamination with herbicydes on the nitrification process. Ecologocal Chemistry and Engineering A, 16(8), 947-952. 
Kulkarni, M. A., \& Chaudhari, A. B. (2006). Biodegradation of p-nitrophenol by P. putida. Bioresource Technology, 97, 982-988.

Lane, D. J. (1991). 16S/23S rRNA sequencing. In E. Stackebrant \& M. Goodfellow (Eds.), Nucleic acid techniques in bacterial systematic (pp. 115-175). London: Wiley.

Lesan, H. M., \& Bhandari, A. (2003). Atrazine sorption on surface soils: time-dependent phase distribution and apparent desorption hysteresis. Water Research, 37, 1644-1654.

Marecik, R., Króliczak, P., Czaczyk, K., Biała, W., Olejnik, A., \& Cyplik, P. (2008). Atrazine degradation by aerobic microorganisms isolated from the rhizosphere of sweet flag (Acorus calamus L.). Biodegradation, 19, 293-301.

Martin, J. (1950). Use of acid, rose bengal, and streptomycin in the plate method for estimating soil fungi. Soil Science, $69,215-233$

Martínez, J. (2004). Practical guideline on environmentally sound management of obsolete pesticides. In: S. Aguinaga (ed.). Basel convention coordinating centre for Latin America and the Caribbean, Montevideo, Uruguay, November 2004

Martínez-Toledo, M. V., Salmerón, V., Rodelas, B., Pozo, C., \& González-López, J. (1998). Effects of the fungicide captan on some functional groups of soil microflora. Applied Soil Ecology, 7, 245-255.

Matyjaszczyk, E. (2008). Rejestracja środków ochrony roślin w Polsce- uwarunkowania i stan aktualny (The registration of resources of the plants protection in Poland - conditionings and the current state). Progress in Plant Protection, $48(1), 1-7$.

Millioli, V. S., Servul, E.-L. C., Sobral, L. G. S., \& de Carvalho, D. D. (2009). Bioremediation of crude oilbearing soil: evaluating the effect of rhamnolipid addition to soil toxicity and to crude oil biodegradation efficiency. Global NEST Journal, 11(2), 181-188.

Monard, C., Martin-Laurent, F., Vecchiato, C., Francez, A. J., Vandenkoornhuyse, P., \& Binet, F. (2008). Combined effect of bioaugmentation and bioturbation on atrazine degradation in soil. Soil Biology and Biochemistry, 40, 2253-2259.

Mondragon-Parada, M. E., Ruiz-Ordaz, N., Tafoya-Garnica, A., Juarez-Ramirez, C., Curiel-Quesada, E., \& GalindezMayer, J. (2008). Chemostat selection of a bacterial community able to degrade $s$-triazinic compounds: continuous simazine biodegradation in a multi-stage packed bed biofilm reactor. Journal of Industrial Microbiology and Biotechnology, 35, 767-776.

Moreno, J. L., Aliaga, A., Navarro, S., Hernandez, T., \& Garcia, C. (2007). Effects of atrazine on microbial activity in semiarid soil. Applied Soil Ecology, 35, 120-127.

Naidoo, V., \& Buckley, C. A. (2003). Survey of pesticide wastes in South Africa and review of treatment options. WRC Report No 1128/1/03. Pretoria: WRC. 64.

Nishino, S. F., \& Spain, J. C. (1993). Degradation of nitrobenzene by a Pseudomonas pseudoalcaligenes. Applied Environmental Microbiology, 59, 2520-2525.

Oh, B., Shea, P. J., Drijber, R. A., Vasilyeva, G. K., \& Sarath, G. (2003). TNT biotransformation and detoxification by $P$. aeruginosa sp. Biodegradation, 14, 309-319.
Omar, S. A., \& Abdel-Sater, M. A. (2001). Microbial populations and enzyme activities in soil treated with pesticides. Water, Air, and Soil Pollution, 127, 49-63.

Perucci, P., Dumontet, S., Bufo, S. S., Mazzatur, A., \& Casucci, C. (2000). Effect of organic amendment and herbicide treatment on soil microbial biomass. Biology and Fertility of Silos, 32, 17-23.

Przybulewska, K., \& Taborska, J. (2008). An attempt to determine the resistance of microorganisms from triazinecontaminated soils to different herbicide groups. Ecological Chemistry and Engineering, 15(3), 359-374.

Ralebitso, T. K., Senior, E., \& van Verseveld, H. W. (2002). Microbial aspects of atrazine degradation in natural environments. Biodegradation, 13, 11-19.

Rousseaux, S., Hartmann, A., \& Soulas, G. (2001). Isolation and characterization of new Gram-negative and Grampositive atrazine degrading bacteria from different French soils. FEMS Microbiology Ecology, 36, 211-222.

Różański, L. (1992). Przemiany pestycydów w organizmach żywych $i$ środowisk. Warszawa: Państwowe Wydawnictwo Rolnicze $i$ Leśne. (Conversions of pesticides in lively organisms and in the environment. Warsaw: State Agricultural and Forest Publisher.

Sánchez, M., Garbi, C., Martinez-Àlwarezv, R., Ortiz, L. T., Allendeb, J. L., \& Martìn, M. (2005). Klebsiella planticola strain DZS mineralizes simazine: physiological adaptation involved in the process. Applied Microbiology and Biotechnology, 66, 589-596.

Singh, N., Megharaj, M., Kookana, R. S., Naidu, R., \& Sethunathan, N. (2004). Atrazine and simazine degradation in Pennisetum rhizosphere. Chemosphere, 56, 257-263.

Stobiecki, S., Fuszera, E., Baron, L., Siłowiecki, A., \& Stobiecki, T. (2003). Likwidacja odpadów pestycydowych w cementowni- możliwości techniczne a praktyka (The liquidation of pesticidal waste material in the cement mill - technical possibilities and the practice). Progress in Plant Protection, 43(1), 389-398.

Topp, E. (2001). A comparison on three atrazine-degrading bacteria for soil bioremediation. Biology and Fertility of Silos, 33, 529-534.

Vela, N., Navarro, G., Gimenes, M. J., \& Navarro, S. (2004). Gradual fall of $s$-triazine herbicides in drinking and wastewater samples as influenced by light and temperature. Water, Air, and Soil Pollution, 158, 3-19.

Vibber, L. L., Pressier, M. J., \& Colores, G. M. (2007). Isolation and characterization of novel atrazine-degrading microorganism from an agricultural soil. Applied Microbiology and Biotechnology, 75, 921-928.

Wilson, P. C., Whitwell, T., \& Klaine, S. J. (2000). Phytotoxicity, uptake, and distribution of 14C-simazine in Acorus gramenius and Pontederia cordata. Weed Science, 48(6), 701-709.

Yatmaz, H. C., \& Uzman, Y. (2009). Degradation of pesticide monochrotophos from aqueous solution by electrochemical method. International Journal of Electrochemical Scence, 4, 614-626.

Zlotnikov, A. K., Sadovnikova, L. K., Balandina, A. V., Zlotnikov, K. M., \& Kazakov, A. V. (2007). Usage of Albit for recultivation of oil-polluted soils. Vestnik RASHN, 1, 65-67. 